\title{
Complexation Properties of the Chelating Resin Functionalized with Iminodiacetic Acid. Application to Column Separation of Molybdenum and Tungsten
}

\author{
Mohammed H. H. Mahmoud, Masatoshi Kanesato, Toshiro Yokoyama \\ and Toshishige M. Suzuki ${ }^{\dagger}$ \\ Tohoku National Industrial Research Institute, Nigatake, Miyagino, Sendai 983, Japan
}

\begin{abstract}
A chelating polymer resin having iminodiacetic acid (IDA) as the functional group has been prepared for the selective adsorption of oxo-molybdenum(VI) or oxo-tungsten(VI). The ${ }^{13} \mathrm{C}$ - and ${ }^{1} \mathrm{H}-\mathrm{NMR}$ spectra of these IDA complexes have been studied in the $\mathrm{pH}$ range of $4-7$ to elucidate the complexation properties of the functional group. The NMR study in the homogeneous system suggests that the IDA forms a $1: 1$ complex with $\mathrm{Mo}^{\mathrm{VI}}$ and $\mathrm{W}^{\mathrm{VI}}$ in the $\mathrm{pH}$ region $4-7$. The peak integration of coordinated acetate signals indicates that the complex formation of IDA is much favorable with Mo ${ }^{\mathrm{VI}}$ than with $\mathrm{W}^{\mathrm{v}}$. A selective adsorption of $\mathrm{Mo}^{\mathrm{v}}$ over $\mathrm{W}^{\mathrm{vI}}$ has been realized by the chelating resin having an IDA group. A mutual separation of $\mathrm{Mo}^{\mathrm{VI}}$ and $\mathrm{W}^{\mathrm{VI}}$ has been demonstrated by the IDA resin in a column system.
\end{abstract}

Keywords Chelating resin, iminodiacetate, complexation property, molybdenum, tungsten, column separation

Highly purified molybdenum and tungsten have become tremendously important in industries. Since the chemical properties of molybdenum and tungsten are very similar ${ }^{1,2}$, their mutual separation usually requires tedious procedures. For the separation of metals, there is a growing interest in the use of hydrometallurgical techniques, including solvent extraction ${ }^{3}$ and ionexchange processes.,5 Ion-exchange methods are being applied to the analytical separation of molybdenum and tungsten; ${ }^{5}$ still the selectivity of the conventional anionexchangers toward anionic oxo-molybdenum(VI) and oxo-tungsten(VI) ions is not sufficiently high to allow their clear separation.

Chelating polymer resins containing a highly selective complexing group are one of the attractive candidates for the metal separation procedure because of their high selectivity and operational convenience. ${ }^{6}$ The selectivity of the chelating resin is mainly attributed to the nature of the chelating reagent fixed on the polymer support. Iminodiacetic acid (IDA) is the most popular functional group for a chelating resin that can form stable complexes with metal ions of high valency. We have measured the ${ }^{1} \mathrm{H}$ - and ${ }^{13} \mathrm{C}-\mathrm{NMR}$ spectra of IDA in the presence of molybdenum(VI) or tungsten(VI) to elucidate the ligand selectivity toward these metal ions. A part of the work has been reported briefly. ${ }^{7}$ This is the full detailed paper dealing with the NMR study, preparation of the chelating resin, adsorption characteristic of the resin and the application to the column separation of molybdenum(VI) and tungsten (VI).

\footnotetext{
$\dagger$ To whom correspondence should be addressed.
}

\section{Experimental}

\section{Materials}

Reagent grade $\mathrm{Na}_{2} \mathrm{MoO}_{4} \cdot 2 \mathrm{H}_{2} \mathrm{O}$ and $\mathrm{Na}_{2} \mathrm{WO}_{4} \cdot 2 \mathrm{H}_{2} \mathrm{O}$ were used for the preparation of metal ion stock solutions. Analytical grade iminodiacetate and diethyliminodiacetate were used without further purification. All other reagents and solvents were analytical grade.

IDA resin was prepared according to the following procedure. A suspension of chloromethylated styrene10\%-divinyl benzene copolymer beads (macroreticular type; surface area, $7.3 \mathrm{~m}^{2} \mathrm{~g}^{-1}$; mean pore diameter, $720 \AA$; $\mathrm{Cl}, 17.1 \% ; 30-60 \mathrm{mesh})(25 \mathrm{~g})$ and diethyliminodiacetate $(47.6 \mathrm{~g})$ in $270 \mathrm{~cm}^{3}$ of dioxane was refluxed for $24 \mathrm{~h}$ under stirring. The resin beads were filtered off and were washed with ethanol. To the resin beads a $250 \mathrm{~cm}^{3}$ of $1 \mathrm{M}\left(\mathrm{M}=\mathrm{mol} \mathrm{dm} \mathrm{dm}^{-3}\right)$ sodium hydroxide solution was added and the suspension was refluxed for $24 \mathrm{~h}$. The beads were filtered off, washed with water and then immersed in $2 \mathrm{M}$ hydrochloric acid overnight. After being washed with water, the resin beads were transferred to a Soxhlet extractor, extracted with ethanol, and then dried in vacuo. The yield of the IDA resin was $33.5 \mathrm{~g}$. The nitrogen content of the IDA resin was $4.2 \%$ (ligand content was $3.0 \mathrm{mmol} / \mathrm{g}$-resin).

\section{Adsorption capacity}

Equilibrium adsorption capacity (amount of metal ion adsorbed on one gram of the resin) was determined in a batchwise technique with the metal ion always being in excess over the resin capacity. Typically, $100 \mathrm{mg}$ of dry resin was added to $100 \mathrm{~cm}^{3}$ of metal ion solution $\left(5 \times 10^{-3}\right.$ 
M) of various pH. After the solution was shaken for $2 \mathrm{~d}$ at $25^{\circ} \mathrm{C}$, the equilibrium $\mathrm{pH}$ and the amount of metal ion remaining in the solution were determined. The capacity of the resin was calculated by the difference observed between the initial and the final metal ion concentration.

\section{Measurements}

The metal ion concentration was determined by an inductively coupled plasma atomic emission spectrometer, Seiko Model SPS-1200A. The ${ }^{1} \mathrm{H}-\mathrm{NMR}$ and ${ }^{13} \mathrm{C}$-NMR spectra were measured in $\mathrm{D}_{2} \mathrm{O}$ by a Varian VXR-300 spectrometer with sodium 3-(trimethylsilyl)propanesulfonate as the internal standard. A digital $\mathrm{pH}$ meter, TOA Model HM-18E, was used for the $\mathrm{pH}$ measurements. The $\mathrm{pH}$ values of solutions were adjusted with phosphate buffer in the $\mathrm{pH}$ range of 6-8, with acetate buffer in the $\mathrm{pH}$ range of 3-5 and with hydrochloric acid below 3 .

\section{Adsorption rate}

The adsorption rate of the metal ion was determined in a batchwise experiment. One gram of dry resin was swollen with water and was added to $100 \mathrm{~cm}^{3}$ buffered metal ion solutions $\left(5 \times 10^{-4} \mathrm{M}\right)$ of various $\mathrm{pH}$ values. While stirring, small portions of the samples were withdrawn at appropriate intervals and the metal ion concentration was determined.

\section{Distribution coefficient}

In a solid ion exchanger such as polymer chelating resin, the distribution coefficient is defined as ${ }^{8}$

$$
K_{\mathrm{d}}=\frac{\text { amount of metal ion per } \mathrm{g} \text { of dry resin }}{\text { amount of metal ion per } \mathrm{cm}^{3} \text { of solution }}
$$

The equilibrium distribution coefficient of metal ion was determined under a batchwise procedure. One gram portion of dry resin was added to a $100 \mathrm{~cm}^{3}$ buffered metal ion solution $\left(1 \times 10^{-3} \mathrm{M}\right)$. After shaking for seven days at $25^{\circ} \mathrm{C}$, the equilibrium $\mathrm{pH}$ and the amount of metal ion remained in the solution were determined. The $K_{d}$ value was calculated according to the formula given above.

\section{Column-breakthrough experiments}

Column separation of $\mathrm{Mo}^{\mathrm{VI}}$ and $\mathrm{W}^{\mathrm{VI}}$ was typically carried out as follows: Five grams of resin was swollen with water and then poured onto a glass column $(\phi$ $1.0 \mathrm{~cm}$ ). The column was conditioned with $0.5 \mathrm{M}$ acetate buffer (pH 5) prior to use. Equimolar amounts of $\mathrm{Mo}^{\mathrm{vi}}$ and $\mathrm{W}^{\mathrm{vi}}\left(5 \times 10^{-3} \mathrm{M}\right.$ each) were passed through the column continuously at a rate of $1 \mathrm{~cm}^{3} \mathrm{~min}^{-1}$. The effluent was fractionated into $20 \mathrm{~cm}^{3}$ portions and the amount of the metal ions was detetermined. The adsorbed $\mathrm{Mo}^{\mathrm{VI}}$ and/or $\mathrm{W}^{\mathrm{VI}}$ was liberated from the column by elution with $1 \mathrm{M}$ sodium hydroxide solution. The solution coming out of the column was fractionated again and the amount of metal ions was determined.
The column was ready to use again after washing first with dilute hydrochloric acid, then with water.

\section{Results and Discussion}

\section{NMR study}

One of the characteristic features of oxo-molybdenum (VI) and oxo-tungsten(VI) is that they change their chemical form depending on $\mathrm{pH}$ of the solution as well as on the concentration of metal ion. ${ }^{9}$ This makes the separation of $\mathrm{Mo}^{\mathrm{VI}}$ and $\mathrm{W}^{\mathrm{vI}}$ quite difficult by anion exchange methods. In basic media, the major species are mononuclear $\mathrm{MoO}_{4}{ }^{2-}$ and $\mathrm{WO}_{4}{ }^{2-}$, but they tend to form polynuclear anions in acidic media. Mononuclear $\mathrm{MoO}_{4}{ }^{2-}$ begins to form at $\mathrm{pH}$ higher than 5 , while that of $\mathrm{W}^{\mathrm{VI}}$ exists at a much higher $\mathrm{pH}$ region. ${ }^{10}$

The ${ }^{13} \mathrm{C}$-NMR spectra of IDA were measured at $\mathrm{pH} 6$ in $\mathrm{D}_{2} \mathrm{O}$ with the presence of equimolar amount of $\mathrm{Mo}^{\mathrm{vi}}$ or $\mathrm{W}^{\mathrm{vi}}$ (Fig. 1). Iminodiacetic acid gives two ${ }^{13} \mathrm{C}-\mathrm{NMR}$
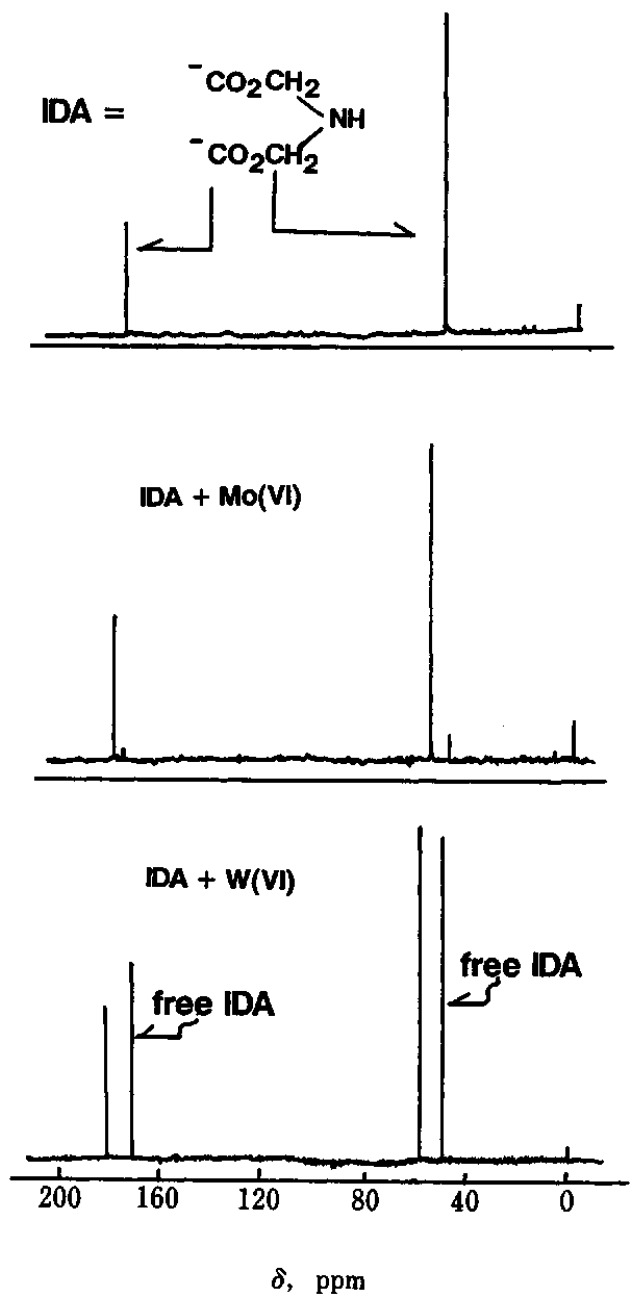

Fig. 1 The ${ }^{13} \mathrm{C}-\mathrm{NMR}$ spectrum of iminodiacetic acid and the spectra measured in the presence of equimolar amounts of $\mathrm{Mo}^{\mathrm{VI}}$ and $\mathrm{W}^{\mathrm{VI}}$ at $\mathrm{pH} 6$ in $\mathrm{D}_{2} \mathrm{O}$. 


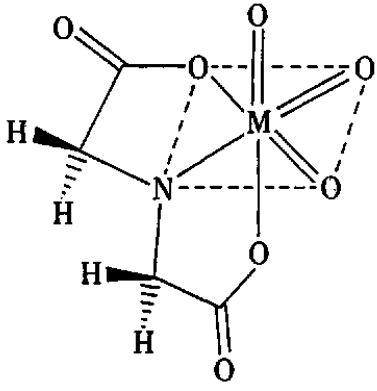

Fig. 2 Schematic structure of the IDA complex, $\left[\mathrm{MO}_{3}(\mathrm{IDA})\right]^{2-}$ $(\mathrm{M}=\mathrm{Mo}, \mathrm{W})$.
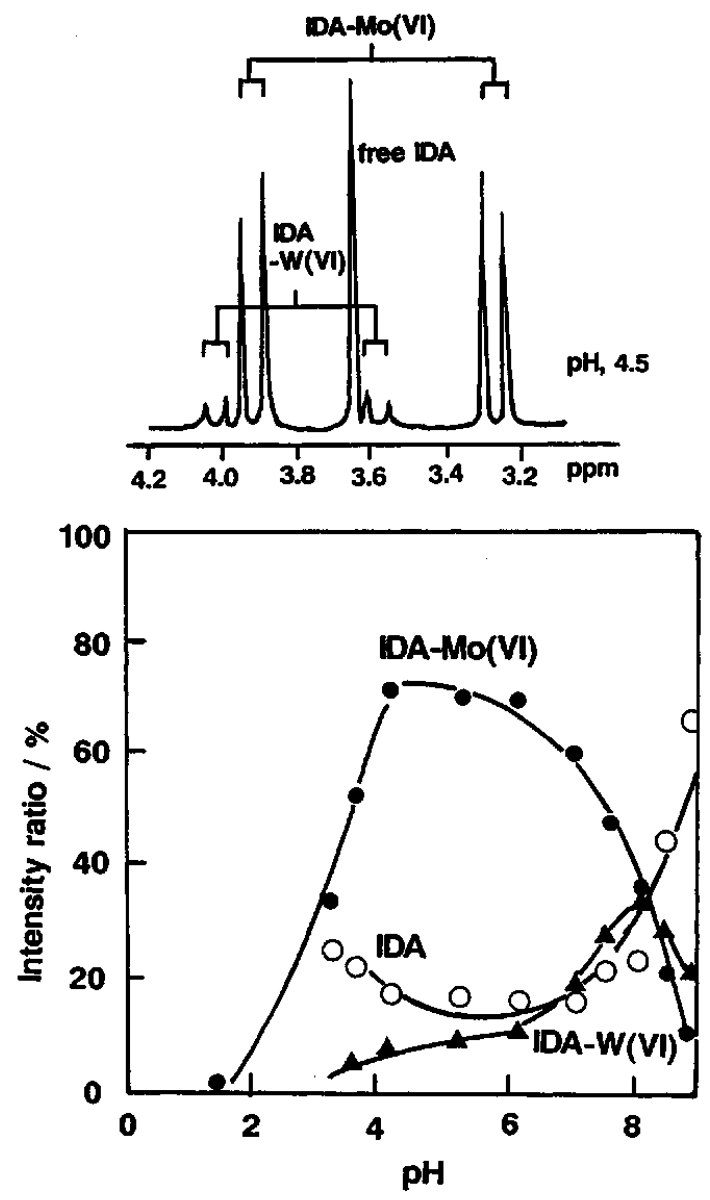

Fig. 3 The intensity ratio of signals due to acetate protons as a function of $\mathrm{pH}$ for the equimolar mixture of $\mathrm{Mo}^{\mathrm{vl}}, \mathrm{W}^{\mathrm{VI}}$ and IDA. The intensities of each species i.e., IDA-Mo ${ }^{\mathrm{vI}}$, IDA$\mathrm{W}^{\mathrm{VI}}$ complexes and free IDA were calculated by the peak integration of the acetate protons. The concentration of IDA, $\mathrm{Mo}^{\mathrm{VI}}$ and $\mathrm{W}^{\mathrm{VI}}$ were $0.2 \mathrm{M}, 0.1 \mathrm{M}$ and $0.1 \mathrm{M}$, respectively. The spectra were measured in $\mathrm{D}_{2} \mathrm{O}$.

peaks corresponding to the acetate carbons. These two peaks shift 6.9 and $6.5 \mathrm{ppm}$ down the field upon addition of an equimolar amount of $\mathrm{Mov}^{\mathrm{vt}}$. The peaks for the free IDA almost disappeared due to complete complexa- tion. ${ }^{11}$ Four ${ }^{13} \mathrm{C}$ peaks corresponding to free and coordinated acetate groups were observed in the presence of $\mathrm{W}^{\mathrm{v}}$. The ${ }^{1} \mathrm{H}-\mathrm{NMR}$ spectra of the IDA-Mo ${ }^{\mathrm{VI}}$ and IDA$\mathrm{W}^{\mathrm{v}}$ solution show quartet peaks corresponding to the typical $\mathrm{AB}$ pattern of the coordinated acetate protons ${ }^{12}$ at $\mathrm{pH} 4-7$. The clear quartet peaks suggest the formation of fixed chelating ring of rigid conformation. Only the structure given in Fig. 2 can explain the observed couplet. Thus, at this $\mathrm{pH}$ region IDA forms a 1:1 complex with $\mathrm{Mo}^{\mathrm{vl}}$ in which two acetate arms of IDA coordinate symmetrically to the $\mathrm{MoO}_{3}$ core. In case of $\mathrm{W}^{\mathrm{v}}$, on the other hand, free IDA protons were observed as the major peak, along with the small quartet peaks of the coordinated acetate protons. In agreement with the results of ${ }^{13} \mathrm{C}$-NMR spectra, the intense peak of free acetate protons in ${ }^{1} \mathrm{H}-\mathrm{NMR}$ suggests less favorable complexation of IDA with $\mathrm{W}^{\mathrm{v}}$. The ${ }^{1} \mathrm{H}-\mathrm{NMR}$ spectra of equimolar mixture of $\mathrm{Mo}^{\mathrm{vi}_{\mathrm{I}}}, \mathrm{W}^{\mathrm{vi}}$ and IDA were measured at various $\mathrm{pH}$ values. The peak intensity of the free and complexed acetate signals was plotted as a function of pH (Fig. 3). The peak intensity of the coordinated acetate protons is always larger in the presence of $\mathrm{Mo}^{\mathrm{VI}}$ than that in the presence of $\mathrm{W}^{\mathrm{vl}}$. Thus the IDA forms a metal complex with $\mathrm{Mo}^{\mathrm{v}}$ rather than with $\mathrm{W}^{\mathrm{vI}}$ in the $\mathrm{pH}$ range measured.

\section{Equilibrium adsorption capacity}

On the basis of NMR studies, the chelating resin having IDA group looks promising for the preferential uptake of $\mathrm{Mo}^{\mathrm{vI}}$ rather than $\mathrm{W}^{\mathrm{vI}}$. The adsorption capacity $v s . \mathrm{pH}$ profile of the IDA resin is shown in Fig. 4. The adsorption of $\mathrm{Mo}^{\mathrm{V}}$ is much more favorable than that of $\mathrm{W}^{\mathrm{v}}$. We observed that the adsorption of $\mathrm{Mo}^{\mathrm{vl}}$ is always accompanied with the increase in $\mathrm{pH}$ of the solution suggesting that protons are withdrawn from the solution upon coordination. The maximum capacity for $\mathrm{Mo}^{\mathrm{vl}}$ is $2.2 \mathrm{mmol} \mathrm{g}^{-1}$, which is less than the estimated content of the functional group of the IDA resin (3.0 $\mathrm{mmol} \mathrm{g}^{-1}$ ). The IDA resin appeared to form a 1:1 complex with $\mathrm{Mo}^{\mathrm{vI}}$, in analogy with the solution phase.

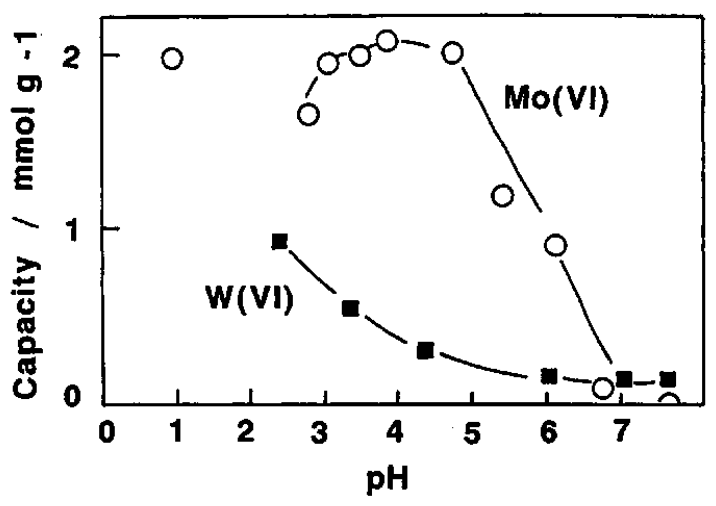

Fig. 4 Equilibrium adsorption capacity of the IDA resin for $\mathrm{Mo}^{\mathrm{VI}}$ and $\mathrm{W}^{\mathrm{VI}}$ as a function of $\mathrm{pH}$. IDA resin, $0.1 \mathrm{~g}$; metal concentration, $5 \times 10^{-3} \mathrm{M}\left(100 \mathrm{~cm}^{3}\right)$. 


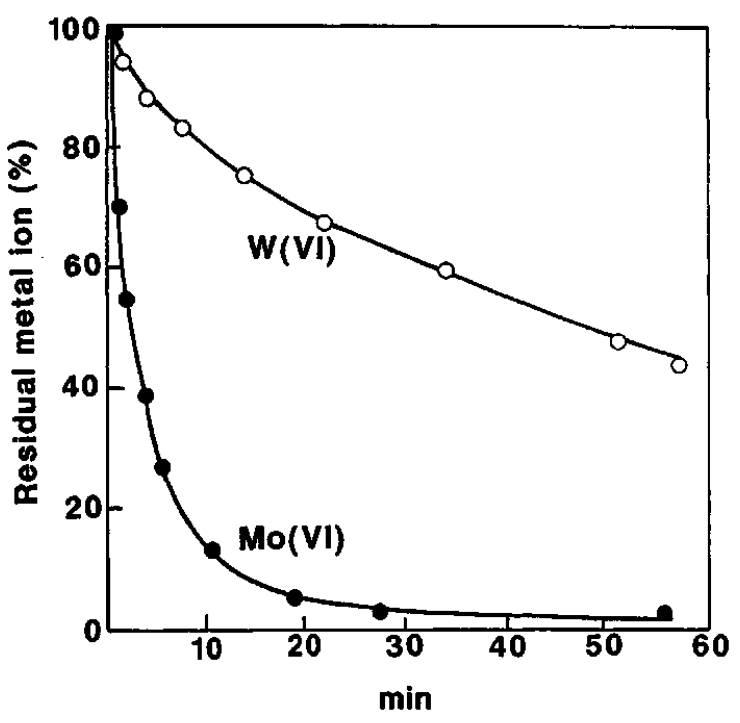

Fig. 5 Time courses for the adsorption of $\mathrm{Mo}^{\mathrm{VI}}$ and $\mathrm{W}^{\mathrm{VI}}$ with the IDA resin. IDA resin, $1 \mathrm{~g}$; metal concentration, $5 \times 10^{-4}$ $\mathrm{M}\left(100 \mathrm{~cm}^{3}\right) ; \mathrm{pH}, 4.5$.

On the contrary, the capacity of $\mathrm{W}^{\mathrm{vi}}$ is remarkably lower than that of molybdenum in the $\mathrm{pH}$ range $4-5.5$. The capacity slightly increased at acidic $\mathrm{pH}$ region. Practically no adsorption of $\mathrm{Mo}^{\mathrm{VI}}$ nor of $\mathrm{W}^{\mathrm{vl}}$ takes place at basic $\mathrm{pH}$ region. In fact adsorbed $\mathrm{Mo}^{\mathrm{vl}}$ and $\mathrm{W}^{\mathrm{vl}}$ were readily liberated from the resin on treatment with $1 \mathrm{M}$ sodium hydroxide solution.

\section{Adsorption rate}

Although the equilibrium capacity and the distribution coefficients are of fundamental importance in characterizing the chelating resin, the rate of adsorption is extremely important from a practical point of view. The time-courses of $\mathrm{Mo}^{\mathrm{V} 1}$ and $\mathrm{W}^{\mathrm{VI}}$ adsorption on IDA resin were examined at pH 4:5. The result is given in Fig. 5. At $\mathrm{pH}$ lower than 3, the adsorptions of both $\mathrm{Mo}^{\mathrm{VI}}$ and $\mathrm{W}^{\mathrm{vI}}$ were slow, and the equilibrium was not attained even after $2 \mathrm{~h}$. At pH around 4-5, the adsorption of $\mathrm{Mo}^{\mathrm{vI}}$ was fast and the equilibrium was attained in $50 \mathrm{~min}$, while that of $\mathrm{W}^{\mathrm{vi}}$ required much more time. At $\mathrm{pH}$ higher than 6 , the adsorption for $\mathrm{Mo}^{\mathrm{VI}}$ was fast initially, and started to slow down after $20 \mathrm{~min}$, but very slow adsorption of $\mathrm{W}^{\mathrm{vI}}$ was observed. These results show that the $\mathrm{pH}$ region around $4-5$ is most favorable for the separation of $\mathrm{Mo}^{\mathrm{vl}}$ and $\mathrm{W}^{\mathrm{v}}$.

\section{Distribution coefficient}

The distribution coefficients of $\mathrm{Mo}^{\mathrm{VI}}$ and $\mathrm{W}^{\mathrm{VI}}$ with the IDA resin were examined as a function of $\mathrm{pH}$. The results are given in Fig. 6. The $\log K_{d} v s$. pH curves clearly imply that the adsorption of $\mathrm{Mo}^{\mathrm{VI}}$ by the IDA resin is always superior to that of $\mathrm{W}^{\mathrm{v}}$. This is in good accordance with the results of NMR studies. The large difference of $K_{\mathrm{d}}$ value in the $\mathrm{pH}$ range of $4-5.5$ suggests the possibility of the column separation of two metal

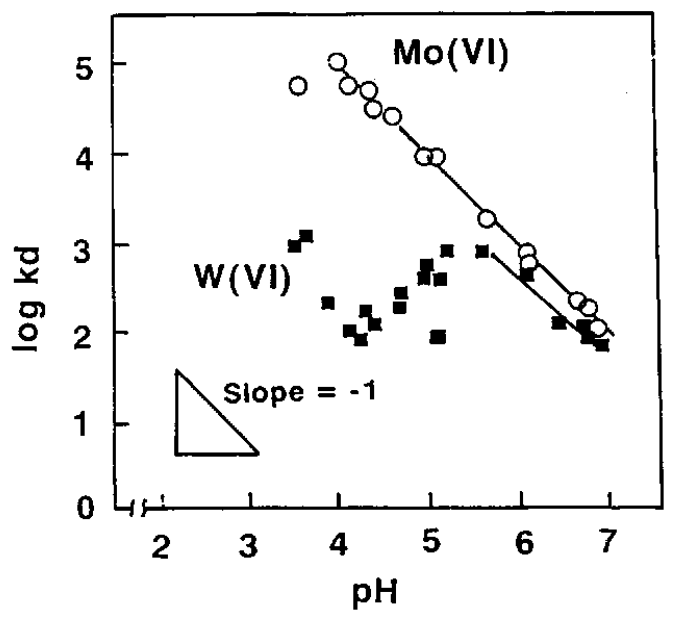

Fig. 6 The distribution coefficient of $\mathrm{Mo}^{\mathrm{VI}}$ and $\mathrm{W}^{\mathrm{VI}}$ with the IDA resin. IDA resin, $1.0 \mathrm{~g}$; metal concentration, $1 \times 10^{-3} \mathrm{M}$ $\left(100 \mathrm{~cm}^{3}\right)$.

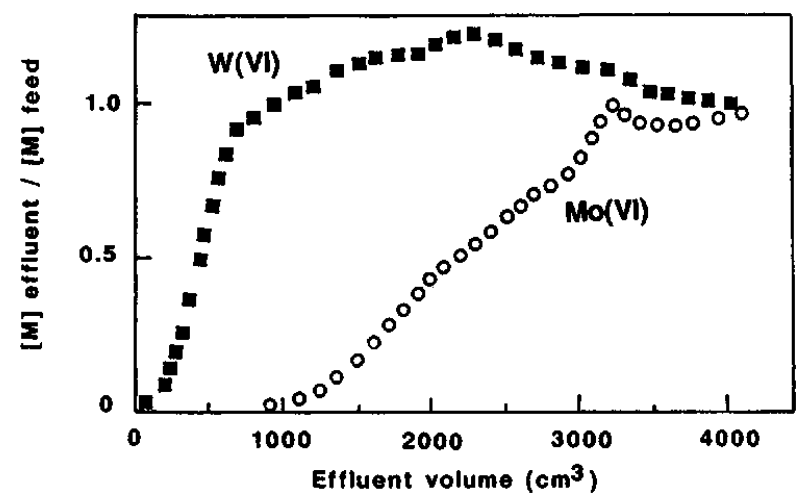

Fig. 7 The column breakthrough profile for the separation of $\mathrm{Mo}^{\mathrm{VI}}$ and $\mathrm{W}^{\mathrm{VI}}$. Bed resin, $5 \mathrm{~g}\left(19.6 \mathrm{~cm}^{3}\right) ; \mathrm{pH}, 5$; buffer, $0.5 \mathrm{M}$ acetate buffer; metal ion feed, $5 \times 10^{-3} \mathrm{M}$ each; flow rate, $1 \mathrm{~cm}^{3} \mathrm{~min}^{-1}$.

ions. The large $K_{\mathrm{d}}$ values for $\mathrm{Mo}^{\mathrm{vI}}$ at $\mathrm{pH} 4-5.5$ indicate that $\mathrm{Mo}^{\mathrm{v1}}$ is adsorbed nearly completely on the IDA resin. The $\mathrm{Mo}^{\mathrm{VI}}$ can be retained in the resin as the mononuclear complex with IDA group, in analogy with homogeneous solution. Therefore, facile dissociation of polynuclear species into mononuclear ones may take place in the presence of IDA resin to form 1:1 complexes with the functional group. Complexation of $\mathrm{W}^{\mathrm{vI}}$ with IDA group is less favorable, presumably due to the higher stability of polynuclear species in the solution., ${ }^{9,10}$ The $K_{\mathrm{d}}$ vs. $\mathrm{pH}$ profile indicates that the complex formation of IDA group both with $\mathrm{Mo}^{\mathrm{VI}}$ and $\mathrm{W}^{\mathrm{VI}}$ is unlikely in basic media because the base hydrolysis should compete with the complexation. ${ }^{13}$

\section{Column separation of molybdenum(VI) and tungsten(VI)}

In the batch experiments, the IDA resin showed an apparent selectivity toward $\mathrm{Mo}^{\mathrm{vi}}$ over $\mathrm{W}^{\mathrm{vi}}$ at $\mathrm{pH}$ values 
ranging from 4 to 6 . This suggests the efficient separation of the two metal ions. We have examined the selective retainment of $\mathrm{Mo}^{\mathrm{vI}}$ by the column system. A solution of given $\mathrm{pH}$ containing equimolar amounts of $\mathrm{Mo}^{\mathrm{vI}}$ and $\mathrm{W}^{\mathrm{v}}$ was continuously passed through the column; the metal ions in the effluent were determined. The pH of the feed solution is one of the most important parameters, since it greatly affects the separation efficiency. Figure 7 shows typical breakthrough curves at $\mathrm{pH}$ 5.0. The retained metal ions were quantitatively released from the column by elution with $1 \mathrm{M}$ sodium hydroxide solution. The optimum $\mathrm{pH}$ value for successful separation is around 5: the amount of $\mathrm{Mo}^{\mathrm{vl}}$ retained in the resin is much larger and the leaking of $\mathrm{W}^{\mathrm{vI}}$ is faster than that under any other $\mathrm{pH}$ conditions. At higher $\mathrm{pH}$, both metals quickly appeared out of the column without effective adsorption. Thus the efficiency of the column separation was most favorably operated at around $\mathrm{pH} 5.0$.

In conclusion, the ${ }^{13} \mathrm{C}$ - and ${ }^{1} \mathrm{H}-\mathrm{NMR}$ spectroscopic study in homogeneous solution provided important information about the complexation behavior of IDA with $\mathrm{Mo}^{\mathrm{v} 1}$ and $\mathrm{W}^{\mathrm{v} 1}$. IDA forms a $1: 1$ complex $\left(\left[\mathrm{MO}_{3}(\mathrm{IDA})\right]^{2-}\right)$ with $\mathrm{MO}_{3}(\mathrm{M}=\mathrm{Mo}, \mathrm{W})$ core in the $\mathrm{pH}$ range of $3-8$. The coordination of IDA toward $\mathrm{Mo}^{\mathrm{VI}}$ is much more favorable than that with $\mathrm{W}^{\mathrm{v}}$. The chelating resin having IDA group revealed a higher adsorptibility of $\mathrm{Mo}^{\mathrm{vi}}$ over $\mathrm{W}^{\mathrm{vi}}$ at $\mathrm{pH} 4-6$. An efficient separation of $\mathrm{Mo}^{\mathrm{vl}}$ and $\mathrm{W}^{\mathrm{vi}}$ was achieved by the column packed with the IDA resin. Thus, iminodiacetate was demonstrated to be an useful functional group of the chelating resin for the selective separation of $\mathrm{Mo}^{\mathrm{v}}$ from $\mathrm{W}^{\mathrm{vI}}$.

\section{References}

1. F. A. Cotton and G. Wilkinson, "Advanced Inorganic Chemistry", p. 804, Chap. 19, John Wiley \& Sons, New York, 1988.

2. R. V. Parish, "The Chemistry of Metallic Elements", Longman Group Ltd., London, 1977.

3. J. Coca, F. V. Diez and M. A. Moris, Hydrometallurgy, 25, 125 (1990).

4. Z. Zhou, "Ion Exchange for Industry", ed. M. Streat, p. 373, SCI, London, 1988.

5. M. Morhol, "Comprehensive Analytical Chemistry", ed. G. Svehla, Vol. 14, p. 291, Elsevier Scientific Publishing Company, New York, 1982.

6. S. K. Sahni and J. Reedijk, Coord. Chem. Rev., 59, 1 (1986).

7. T. M. Suzuki, M. Kanesato, T. Yokoyama and M. H. H. Mahmoud, "Ion Exchange Advances Proceeding of 92", ed. M. Slater, p. 382, SCI, London, 1992.

8. F. Hellferich, "Ion Exchange", p. 127, McGraw-Hill, New York, 1962.

9. A. E. Martell and R. M. Smith, "Critical Stability Constants", Vol. 4, p. 18, Plenum Press, New York and London, 1976.

10. M. Sano, J. Shibata, M. Harada and S. Nishimura, J. Min. Met. Inst., Jpn., 104, 475 (1988).

11. M. A. Freeman, F. A. Schultz and C. N. Reilley, Inorg. Chem., 21, 567 (1982).

12. R. J. Kula, Anal. Chem., 39, 1171 (1967).

13. S. I. Chan, R. J. Kula and D. T. Sawyer, J. Am. Chem. Soc., 86, 377 (1964).

(Received July 20, 1994)

(Accepted October 6, 1994) 